\title{
32. QUATERNARY PALEOCEANOGRAPHY OF THE NORTHEASTERN ATLANTIC: MICROFAUNAL AND STABLE ISOTOPE EVIDENCE AT SITES 548 AND 5491
}

\author{
Michelle H. Caralp, Claude Pujol, Josette Duprat, and Monique Labracherie, Laboratoire de Géologie et \\ d'Océanographie, Université de Bordeaux I \\ and \\ Colette Vergnaud Grazzini, and Jean-François Saliège, Laboratoire de Géologie Dynamique ${ }^{2}$
}

\begin{abstract}
A chronologic scale was developed from the studies of the paleomagnetism, biostratigraphy, and oxygen isotopic stratigraphy of the Site 548 and 549 sediments.

The analysis of the planktonic and benthic foraminifers, radiolarians, and carbon and oxygen isotopic changes suggests that the Quaternary history of paleoceanographic conditions with the deep and surficial water masses can be divided in two distinct phases: (1) from the beginning of the Quaternary to $450,000 \mathrm{yr}$. ago, when environmental and hydrological conditions were uniform; and (2) from 450,000 yr. ago to the present, when climatic and hydrological conditions were fluctuating.
\end{abstract}

\section{INTRODUCTION}

The stratigraphically longest detailed Pliocene-Pleistocene oxygen isotopic record for oceanic sediments extends down to sediments about $2.3 \mathrm{~m}$.y. old. This record is from Core V28-239 from the Pacific Ocean (Shackleton and Opdyke, 1976) and from Core V16-205 from the equatorial Atlantic (van Donk, 1976). More recently, an expanded record of climatic events for the entire Pleistocene has been recognized at Site 517 in the South Atlantic (Vergnaud Grazzini et al., 1984). Other long Pleistocene isotopic records from the North Atlantic have been studied recently: for example, Prell (1983) at DSDP Leg 68, Hole 502B, and Zimmerman et al. (in press) at DSDP Hole 522A. Most of these studies deal with long-term climatic changes, and detailed paleoceanographic reconstructions are available only for late Quaternary time.

The use of hydraulic piston coring during the Leg 80 cruise has resulted in the recovery of a complete sequence of Quaternary sediments on the Goban Spur in the northeastern Atlantic Ocean. Sites 548 and 549 are located in a region that underwent important hydrologic changes during Pleistocene time, apparently in response to cyclic climatic fluctuations and to the moving polar front and subarctic convergence. Thus, during the last glacial maximum, these sites may have been located north of the polar front and north of the subarctic convergence (both recognized at $42^{\circ} \mathrm{N}$ ) (CLIMAP Project members, 1976; Pujol, 1980; Ruddiman and McIntyre, 1981).

\footnotetext{
${ }^{1}$ Granciansky, P. C. de, Poag, C. W., et al., Init. Repts, DSDP, 80: Washington (U.S. Govt, Printing Office).

2 Addresses: (Caralp, Pujol, Duprat, and Labracherie) Laboratoire de Géologie et d'Océanographie, Université de Bordeaux I, Avenue des Facultés, 33405 Talence Cedex, France; (Vergnaud Grazzini and Saliège) Laboratoire de Géologie Dynamique, 4 Place Jussieu, 75230 Paris Cedex 05, France.
}

A chronologic scale has been developed on the basis of paleomagnetism (Townsend, this volume), biostratigraphy (Pujol and Duprat, this volume), and oxygen isotope stratigraphy (Vergnaud Grazzini and Saliège, this volume). Major paleoclimatic and paleohydrologic events have been deduced from faunal and stable isotope analyses (Caralp; Pujol and Duprat; and Vergnaud Grazzini and Saliège, all this volume) and are reported and discussed.

\section{STRATIGRAPHIC FRAMEWORK}

Magnetostratigraphy, biostratigraphy, and oxygen isotope stratigraphy have provided a chronologic time scale for the Quaternary sequences of the Goban Spur.

The base of the Quaternary is placed at the top of the Olduvai magnetic event (site chapter and Townsend, both this volume). This boundary at Site 548 does not correspond to any isotopic shift on the $\delta^{18} \mathrm{O}$ curve; no paleobiologic events occur at this level (Section 548-15-1). This indicates that the official Pliocene/Pleistocene boundary is not a climatic event at Site 548. Bioclimatic events and oxygen and carbon isotopic changes related to the first southward excursion of polar waters occurred before the time corresponding to this stratigraphic boundary (Section 548-15-5).

At Hole 549A, the 16 younger isotopic stages have been recognized. They are in good agreement with the bioclimatic subdivisions made on the basis of quantitative changes in planktonic microfaunas. The same subdivisions have been recognized in the upper part of Hole 548 (Cores 548-1 to 548-10). This time interval, which corresponds approximately to the last 600,000 yr., provides a rather precise chronologic scale.

Analyses done on sediments at the base of Core 549A3 , however, indicate an extremely low sedimentation rate, which does not provide a precise determination of isotopic or bioclimatic stages. At Site 548 it is not possible to identify the isotopic stages between the base of the 
Quaternary and isotopic Stage 16 (between Cores 548-15 and 548-10). Furthermore, the bioclimatic succession for the same interval is not correlatable with the isotopic changes displayed on the $\delta^{18} \mathrm{O}$ curve of benthic or planktonic foraminifers.

Therefore, oxygen isotopic stages are clearly identified down to isotopic Stage 16 at about 600,000 yr. ago. Faunal data confirm this interpretation: the transition between isotopic Stages 13 and 12 corresponds to the last appearance datum (LAD) of Pseudoemiliana lacunosa (Pujos, this volume) and to the first appearance datum (FAD) of Globorotalia hirsuta (Pujol and Duprat, this volume). This transition between isotopic Stages 16 and 17 appears to correspond to the extinction of a part of the Stilostomella and Pleurostomella benthic association at both sites.

A stratigraphic interpretation of the sequences prior to the time of isotopic Stage 16 is difficult to make. The usual succession of isotopic stages recognized for Pacific Core V 28-239 (Shackleton and Opdyke, 1976) is not identifiable, and the morphology of the isotopic stages is not a classic one. Paleomagnetic reversals are more frequent than on the usual scale, and possible reworking and hiatuses in that part of the sedimentary sequence should not be excluded. In such conditions, any subdivision of the early Pleistocene ( 1.8 m.y. to 600,000 yr. ago) into climatic cycles based either on stable isotope or faunal changes is controversial.

\section{PALEOENVIRONMENT}

Deep and shallow paleoenvironments of the water masses have been investigated through microfaunal and stable isotope analyses. A schematic evolution of ecologic water masses and their estimated winter and summer temperatures has been deduced from quantitative analyses of planktonic microfaunas (Pujol and Duprat, this volume) and from carbon and oxygen isotope analyses of Globigerina bulloides (Vergnaud Grazzini and Saliège, this volume). Deep-water circulation and changes in the water mass stratification have been deduced from qualitative and quantitative analyses of benthic foraminifers and from stable isotope analyses of $\mathrm{Pla}$ nulina, Cibicidoides, and Uvigerina species (Caralp, this volume; Vergnaud Grazzini and Saliège, this volume).

\section{Surface-Water Environment}

The biostratigraphic scheme proposed by Pujol and Duprat (this volume) has been made on the basis of the response of planktonic microfaunas to climatic and hydrologic changes. For instance, high abundances of leftcoiling Globigerina pachyderma are presently associated with polar waters and might be used in recognizing southward shifts of these water masses and the polar front. The present geographic position of this front is used today to determine the location of the anticyclonic gyre from which the North Atlantic drift is developed. These observations lead to the identification of two important steps in the climatic evolution recorded in Holes 548 and 549A. The first step, occurring in the late Pliocene, corresponds to the first southward excursion of sinistral Globigerina pachyderma in relatively low num- bers ( $<50 \%$ of the total microfauna). This first step is followed by a significant increase in $\delta^{18} \mathrm{O}$ values recorded by Globigerina bulloides. Such data may be interpreted as reflecting a southward migration of the polar front at that time, which nevertheless remained located north of the sites.

A second step, which corresponds approximately to the transition between isotopic Stages 13 and 12 (about 450,000 yr. ago) is indicated by a significant increase in the amount of left-coiling Globigerina pachyderma during glacial stages. This second step is interpreted as reflecting the migration of polar waters and the polar front south of the site locations during glacial maxima.

Thus, these two steps delimit three periods with distinct paleoenvironments.

1. During the late Pliocene, permanent warm, subtropical water masses (Gulf Stream Gyre) resulted in high values of $\delta^{13} \mathrm{C}$ in planktonic foraminifers.

2. From the Olduvai event to 450,000 yr. ago, water mass distribution changed at the surface and southward excursions of polar waters (and the polar front) occurred during cold episodes. However, the polar front was still located north of the sites (i.e., north of $50^{\circ} \mathrm{N}$ ). Warm periods were still characterized by the presence of warm subtropical waters from the anticyclonic gyre recorded by the low values of $\delta^{18} \mathrm{O}$ in planktonic foraminifers. From our data, climatic oscillations had small amplitude.

3. From 450,000 yr. ago to the present, a hydrologic pattern very similar to the one described for the last climatic cycle (Ruddiman and McIntyre, 1976) apparently occurred. Glacial phases are well marked, and during these phases the polar front has been located south of the Goban Spur sites (i.e., south of $50^{\circ} \mathrm{N}$ ). Well-marked interglacial periods have contributed to the setting of large-amplitude climatic oscillations recorded either by large shifts in $\delta^{18} \mathrm{O}$ values or by strong changes in foraminiferal associations. During this period an intensification of the anticyclonic gyre up until 300,000 yr. ago might have resulted in the occurrence of a relatively high number of the species Globorotalia menardii, which is very rare in present-day conditions. Moreover, upwelling could have occurred at Site 548 during a short period corresponding to oxygen isotopic Stage 13 (Labracherie, this volume).

Successive appearances of Globorotalia truncatulinoides, Globorotalia hirsuta, and Turborotalia humilis are unrelated to any significant isotopic signal. Today these species usually occur together in winter subtropical waters. One may thus speculate that the ecological characteristics of these water masses have changed during the Quaternary.

\section{Deep-Water Environment}

Present-day hydrologic features are shown in Figure 1. They correspond to the superposition of two distinct hydrologic units. The first one, the North Atlantic Deep Water (NADW), is present at Site 549. The second one, having less oxygenated waters, occurs at Site 548.

The study of benthic foraminifers at both sites aids in the reconstruction of the paleohydrologic variations during the Quaternary (Caralp, this volume). 


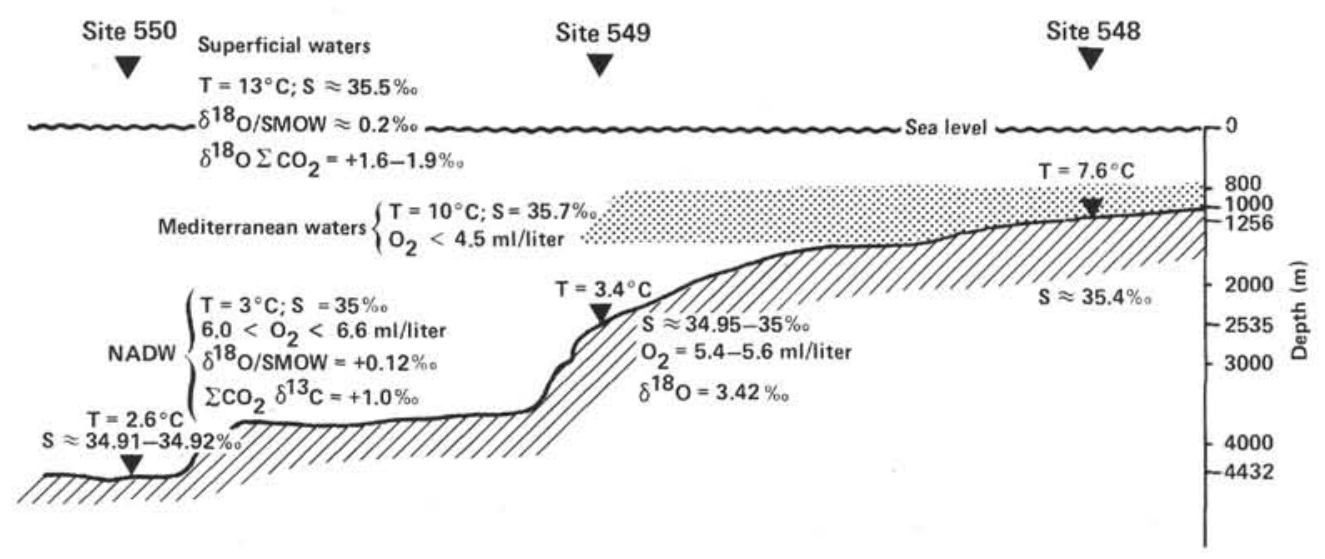

Figure 1. Surface and deep hydrologic setting.

Changes in the oxygen content have also been observed (Fig. 2 [back pocket]). At Hole 549A, which is presently located in waters related to the NADW, glacial stages are marked by a decrease in the dissolved oxygen content, which may result from sluggish deep circulation caused by a decrease in deep-water production or an increase in the distance of deep-water sources. This decrease in oxygen content can also be correlated with a decrease in $\delta^{13} \mathrm{C}$ values during isotopic Stages 6, 10, and 12. Prior to the time of Stage 13, the NADW was present at Site 549.

At Site 548 , a slightly different hydrologic structure can be identified. At present, intermediate waters with a strong Mediterranean component (low oxygen content) are found above the site. Waters similar to the NADW have been identified only during isotopic Stage 5 of the late Pleistocene, which lasted from isotopic Stage 13 to 1. This might indicate that this water mass was $200 \mathrm{~m}$ shallower during isotopic Stage 5. For other stages of the same period, a low oxygen content might indicate a decrease in deep circulation or an increase in the Mediterranean contribution. For the early Pleistocene (from the beginning of the Quaternary up to isotopic Stage 13), oxygenated waters might indicate the occurrence of waters similar to the present day NADW at a depth of 1200 to $1300 \mathrm{~m}$. $\delta^{13} \mathrm{C}$ values recorded by benthic foraminifers are in fact slightly higher in that part of the sequence than for isotopic Stage 5, but the $0.16 \%$ average difference cannot account for such an important change in the identification of deep-water masses (Fig. 2).

\section{Summary}

The Quaternary history of deep-water masses, like that of superficial ecologic water masses, can be divided into two distinct phases.

1. From the beginning of the Quaternary to 450,000 yr. ago, environmental conditions were rather uniform, with an abundant microfauna indicating that deep waters were relatively well oxygenated and rich in nutrients and that hydrologic conditions were relatively stable.

2. From 450,000 yr. ago to the present, a differentiation with depth appeared between Sites 548 and 549. At Site 548 the waters became depleted in oxygen and nutrients and only isotopic Stage 5 is characterized by wa- ters similar to NADW. At Site 549 the changing environment is marked by the influx of waters similar to NADW during all interglacial phases.

It appears then that the variations in the location of the polar front determined from surface hydrology might also be important in explaining the distribution and circulation of deep waters. Deep-water formation, location of deep-water sources, and changes in deep-water fluxes are directly related to climatic variations and influence the hydrologic evolution and the replacement of one type of deep water by another according to the glacial-interglacial succession.

\section{ACKNOWLEDGMENTS}

The writers wish to thank the Deep Sea Drilling Project for having made Leg 80 Quaternary samples available for this study. The CNRS associated laboratory (L.A. 197) of the Bordeaux I University and the Laboratoire Géologie Dynamique of Pierre et Marie Curie University (Paris VI) provided laboratory facilities and technical help. Thanks are extended to G. Oggian for drawing the captions.

We are grateful to W. A. Berggren and W. L. Prell for helpful review. Research was supported in part by Centre National de la Recherche Scientifique through L. A. 197 and E.R.A. 604 and in part by A.T.P. grant "Geology and Geophysics of the Oceans."

\section{REFERENCES}

CLIMAP Project Members, 1976. The surface of the ice-age earth. Science, 101 (4232):1131-1137.

Prell, W. L., 1983. Oxygen and carbon isotope stratigraphy for the Quaternary of Hole 502B: evidence for two modes of isotopic variability. In Prell, W. L., Gardner, J. V., et al., Init. Repts. DSDP, 68: Washington (U.S. Govt. Printing Office), 455-464.

Pujol, C., 1980. Les foraminifères planctoniques de l'Atlantique Nord au Quaternaire. Écologie-Stratigraphie-Environnement. Mem. Inst. Geol. Bassin d'Aquitaine, Bordeaux, No. 10:254.

Ruddiman, W. F., and McIntyre, A., 1976. Northeast Atlantic paleoclimatic change over the past 600,000 years. Mem. Geol. Soc. Am., 145:111-146.

1981. The north Atlantic ocean during the last deglaciation. Palaeogeogr. Palaeoclimat. Palaeoecol., 35:145-214.

Shackleton, N. J., and Opdyke, N. D., 1976. Oxygen isotope and paleomagnetic stratigraphy to Pacific Core V 28-239 late Pliocene to latest Pleistocene. In Cline, R. M., and Hays, J. D. (Eds.), Investigations of Late Quaternary Paleoceanography and Paleoclimatology. Mem. Geol. Soc. Am., 145:449-464.

van Donk, J., 1976. $\mathrm{O}^{18}$ record of the Atlantic Ocean for the entire Pleistocene epoch. In Cline, R. M., and Hays, J. D. (Eds.), Investigations of Late Quaternary Paleoceanography and Paleoclimatology. Mem. Geol. Soc. Am., 145:147-163.

Vergnaud Grazzini, C., Grably, M., Pujol, C., and Duprat, J., 1984. Oxygen isotope stratigraphy and paleoclimatology of southwestern 


\section{H. CARALP ET AL.}

Atlantic Quaternary sediments (Rio Grande Rise) at Deep Sea Drilling Project Site 517. In Barker, P. F., Carlson, R. L., and Johnson, D. A., et al., Init. Repts. DSDP, 72: Washington (U.S. Govt. Printing Office), 871-884.

Zimmerman, H. B., Shackleton, N. J., Backman, J., Kent, D. V., Baldauf, J. G., et al., in press. History of Plio-Pleistocene climate in the Northeastern Atlantic: Deep Sea Drilling Project Hole 552A.

In Roberts, D. G., Schnitker, D., et al., Init. Repts. DSDP, 81:

Washington (U.S. Govt. Printing Office).

Date of Initial Receipt: September 16, 1983

Date of Acceptance: November 23, 1983 